\title{
The environmental, social, and governance (ESG) dimension of firms in which social responsible investment (SRI) and conventional pension funds invest: The mainstream SRI and the ESG inclusion
}

\author{
Mercedes Alda \\ University of Zaragoza, Faculty of Economics and Business, C/Gran Vía, 2, C.P. 50005, Zaragoza, Spain
}

\section{ART ICLE IN F O}

Article history:

Received 14 September 2020

Received in revised form 24 February 2021

Accepted 20 March 2021

Available online $\mathrm{xxx}$

Handling editor. Zhifu Mi

\section{Keywords}

Conventional funds

ESG integration

Mainstream SRI

Pension funds

Portfolio similarity

\begin{abstract}
A B S T R A C T
This study seeks to understand whether the mainstream SRI leads to similar investment decisions in conventional and SRI pension funds. The SRI is expanding beyond specialised SRI funds and increasingly conventional pension funds are integrating firms with certain ESG criteria, in line with legitimacy-theory premises. This phenomenon raises the questions whether SRI and conventional portfolios are converging and whether SRI funds preserve their ethical essence. Using fund holdings and ESG-stock scores, we examine the inclusion level of ESG firms by UK conventional and SRI domestic equity pension funds, taking into account the investment in controversial (socially-sensitive) firms (i.e. related to tobacco, alcohol, or gambling industries, among others). We find that conventional funds consider the firms in which SRI funds invest to integrate ESG criteria. Nonetheless, SRI funds maintain larger ESG-firm standards, preserving the ethical purpose, and larger ESG standards in SRI funds do not affect performance. Our results also show that the ESG integration into conventional funds evolves over time.
\end{abstract}

\section{Introduction}

The Socially Responsible Investment (SRI) has experienced unprecedented development among fund-industries in the last decade. This expansion is due to the progress of specialised SRI funds and the inclusion of ESG (Environmental, Social, and Governance) criteria by conventional funds. Portfolio managers are increasingly developing strategies to also consider non-financial factors, aligning diverse clients' corporate-sustainability values (Nath 2020). The growing awareness of ESG-firm issues, such as environmental scandals or corporate misconducts, has changed investors' conducts towards sustainable investing, transforming the global financial industry (Matallín-Sáez et al., 2019). More and more investors look for firms concerned about the impact of corporate activities, selecting firms involved in cleaner production methods, renewable energies, environmental-responsible technologies, or socially-friendly activities, among others (Jin and Han 2018; Silva and Cortez 2016).

This pressure is making funds aware that ignoring these concerns increases the risk of losing legitimacy (Suchman 1995). Thus, in line with legitimacy-theory principles (Suchman 1995), an increasing number of conventional funds are including investors' concerns and

E-mail address: malda@unizar.es (M. Alda) modifying investment behaviours with the inclusion of ESG-investment criteria. Martí-Ballester (2015) argues that this behaviour may reach similar performance to traditional strategies because investee-fund firms have improved ESG-production processes. In this context, conventional investment-management theories, such as modern portfolio theory, do not fully explain investment conducts based on non-financial factors. Several studies point out that the ESG inclusion may be creating a convergence between the SRI and the traditional management, evolving from a SRI niche to a mainstream SRI (Hellsten and Mallin 2006; Revelli 2017).

Specifically, the SRI niche is based on the selection of ESG assets causing management constraints; however, the mainstream SRI pursues to integrate the ESG dimension into conventional management (Azoulay and Zeller 2006; Revelli 2017). Under the mainstream-SRI framework, SRI funds might not apply too restrictive ESG standards, SRI-information costs may decrease, and performance may improve (Barnett and Salomon 2006; Gangi and Varrone 2018). Nevertheless, this mainstream may produce SRI ambiguities whether SRI boundaries become fuzzy due to a large variety of ESG standards (Nath 2020). This conduct raises the concern about the real ethics of SRI funds (Hellsten and Mallin 2006), revealing the need to analyse whether SRI funds follow SRI-niche tenets or are moving towards the mainstream SRI, prejudicing their ethical standards.

On the other hand, the SRI integration into conventional funds has been enhanced by the inclusion of ESG factors in their fiduciary duty, 
the growing demand to report investments' impact, legislation changes, and the willing to restore their damaged legitimacy during the last financial crisis (In et al., 2014; Joliet and Titova 2018; UNEP FI 2009). Consistent with the framework of legitimacy theory, conventional funds including ESG criteria are fulfilling the social contract that allows the reconnaissance of their purposes, continuing to use social resources, and their survival (Deegan 2002; Lindblom 1994; Schiopoiu and Popa 2013). Thus, the SRI integration may produce the ethicalisation of investment processes, aligning portfolio-construction plans between SRI and conventional funds (Hoepner and Schopohl 2020). Nevertheless, the specific ESG goals of conventional funds depend on managers' priorities to weigh economic and ideological motives (McLachlan and Gardner 2004), which may create ambiguous ESG standards. Consequently, it is necessary to analyse the ESG standards of conventional and SRI portfolios, clarifying whether conventional funds are learning from SRI portfolios or develop own ESG-investment strategies.

The SRI-integration phenomenon is especially expanded among pension funds due to their pro-social behaviour, long-term investment nature, management of large retirement savings, or their high political profile (Sandberg 2013; Sievänen et al., 2017). Pension funds own more than a quarter of global listed stocks, representing $25 \%$ of the organizations accountable for main sustainable development matters (Hoepner and Schopohl 2020). In addition, pension funds are more norm constrained than other institutional investors due to the larger exposure to scrutiny, reinforcing the ESG integration (Hong and Kacperczyk 2009). On the other hand, the long-term investment and the significant equity holdings make pension funds vulnerable to long-term risks. The ESG-investment criteria may help to manage these risks because ESG factors are long-term risk-management indicators (Hoepner and Schopohl 2020). Sethi (2005) finds that pension funds take long-term risks more earnestly due to their commitments to beneficiaries, promoting a more sustainable economy by engaging in responsible investment.

SRI policies among pension funds have increased globally. The UK is one of the pioneers on regulating the ESG disclosure in pension funds (UKSIF 2018). The UK possesses the second largest pension-fund industry with USD 3.6 trillion, representing $7.3 \%$ of OECD pension assets (OECD 2020). Nevertheless, SRI studies on pension funds are scarce (Sandberg 2013; Siëvannen et al., 2017; among others), and no prior works (as far as we know) analyse the mainstream-SRI phenomenon in pension funds, considering legitimacy lens.

This paper contributes to fill the existent gap in the pension-fund literature by analysing whether the mainstream SRI produces a convergence between SRI and conventional pension funds towards firms with similar ESG strategies. Our analyses also help to understand the drivers of incorporating non-financial criteria into investment decisions, considering legitimacy-theory bases. The rest of the paper proceeds as follows. Section "Literature Review" provides an overview of existing literature. Section "Data and Method" describes the data and the methodology. Section "Findings and discussion" contains the results. Section "Conclusions" shows the main conclusions.

\section{Literature review}

The pension-fund management is traditionally explained by modern-portfolio principles. However, the inclusion of non-financial criteria responds to other frameworks, such as legitimacy theory. Under the modern-portfolio theory, fund managers select assets under principles of return maximization, risk minimization, and diversification (Markowitz 1952). Nonetheless, society's norms, values, and beliefs evolve, and managers should adapt investments to these preferences for survival and competitive reasons (Schiopoiu and Popa 2013). The legitimacy theory indicates that, when managers perceive a legitimacy gap, they develop strategies to correct their behaviour and realign with societal desires (Lindblom 1994). Consistent with this premise, the mainstream SRI grows the demand of ESG-investment criteria and, accordingly, funds are increasingly including these criteria.

Despite this change, funds may still build optimal portfolios according to modern-portfolio theory because the legitimacy-theory sustainability is based on managing the connections between traditional norms and modern ethics (Schiopoiu and Popa 2013). Deegan (2002) postulates that the interests of companies and society are both joined by financial issues and contracts. Hence, ESG managerial-investment strategies can maintain and create congruence between funds' social values and societal values. Furthermore, the legitimacy notion to compliance with the social contract may be enhanced in pension funds, given their social nature (Deegan 2002; Sievänen et al., 2017).

Wirth regard to SRI funds, they usually follow SRI-niche tenets by carefully selecting firms with corporate-sustainability business policies. Moreover, SRI funds effort to include financial practices (finance integrates within ethics). In contrast, the mainstream SRI of conventional funds includes ethics within finance (Revelli 2017). This behaviour may lead conventional funds to construct more alike portfolios with regard to SRI funds. Whether SRI and conventional portfolios become more homogeneous, the demand of SRI firms will increase, raising prices and performance (In et al., 2014). Additionally, whether conventional and SRI funds compete in the same market, the market competition will increase, and their differentiation can diminish.

Despite prior arguments, the SRI niche is still growing and SRI funds may desire to preserve their identity by offering differentiate products, investing in companies enhancing corporate sustainability, and effectively balancing the economic and ESG strategies through innovative or cleaner production methods, among others. In et al. (2014) find that SRI funds only compete with other SRI funds due to their unique nature. SRI funds explicitly declare their socially responsible purposes, supplying specialised products to a niche with specific values. On the other hand, conventional funds should account for the diverse value preferences of major clients and financial profitability (Nath 2020). Hence, SRI and conventional funds would not market identical products and SRI-fund managers would maintain the distinctive identity (Nath 2020).

\section{Considering the aforementioned evidence, we hypothesise:}

Hypothesis 1 The mainstream-SRI expansion has increased ESG conventional-fund scores due to larger portfolio-holding similarities with regard to SRI portfolios.

Hypothesis 2 SRI funds maintain higher ESG standards due to SRI specialization and differentiation.

Despite the SRI integration into the conventional-fund segment, Sievänen (2014) identifies obstacles to implement SRI policies (uncertain financial consequences, agency problems, or absence of accepted ESG guidelines). Accordingly, the ESG-screening intensity may diversely affect performance (Gangi and Varrrone 2018). In this regard, conventional investors may not be willing to sacrifice financial benefits whether superior ESG standards increase screening costs, reduce investment opportunities, and negatively affect performance (Aslaksen and Synnestwedt 2003). Borgers et al. (2015) point out that conventional funds may offset these losses by building mixed portfolios with superior ESG assets and controversial assets (i.e. socially-sensitive stocks) $^{1}$ due to the superior risk-adjusted return of controversial assets (Hong and Kacperczyk 2009). This conduct may be explained by the perception risk of legitimacy theory (Deegan 2019); specifically, there is a perception that legitimacy simply manipulates

\footnotetext{
1 Controversial assets, also called "sin stocks" or "socially-sensitive stocks", include tobacco, alcohol, or gambling industries, among others (Borgers et al., 2015; Perez 2016).
} 
opinion, instead of developing actual management changes. Thus, conventional managers may expect that the SRI inclusion is enough to fulfil their social contract. Despite this perception, this behaviour may counteract the legitimacy obtained, and funds should manage it (Ashforth and Gibbs 1990). For example, some conventional funds avoid socially-sensitive stocks because of social considerations, lower arbitrage possibilities, or pricing errors (Borgers et al., 2015; Hong and Kacperczyk 2009; Perez 2016). On the other hand, Nath (2020) finds that some conventional funds limit exposure to exclusionary industries instead of excluding them. Considering previous arguments, we hypothesise:

Hypothesis 3 Larger ESG-portfolio similarities between conventional and SRI funds decrease conventional funds' performance.

Hypothesis 4 Conventional funds use socially-sensitive stocks to offset performance losses caused by ESG constraints.

\section{Data and method}

\subsection{Data}

Our sample is drawn from several sources. The pension-fund data are obtained from Morningstar Direct. We select all UK domestic equity pension funds from January 1999 to November 2019. We identify SRI funds with the "Socially Conscious" Morningstar label (a dichotomous variable -Yes/No-, indicating if a fund is a SRI fund). The data include the daily return, monthly return, monthly Total Net Assets (TNAs), inception-fund date, annual turnover ratios, annual expense ratios, and quarterly portfolio holdings (weights invested in each asset). We exclude index funds for robustness and include live and dead funds to avoid survivorship bias. Pension funds have at least $75 \%$ of their holdings in stocks. The holdings of funds with multiple share classes are common, thus, we aggregate share classes at portfolio level to eliminate duplicates, calculating weighted average return, turnover, and expense ratios, and aggregating the total TNAs of all fund share classes. With regard to funds' qualitative attributes (name, inception date), we keep the class with the longest history (Joliet and Titova 2018). The resulting sample is formed by 359 pension funds (331 conventional and 28 SRI funds). These funds invest in 4697 distinct stocks over the period studied. From the fund-inception date, we obtain the fund age. The fund performance is the monthly four-factor alpha of Carhart (1997), ${ }^{2}$ estimated with 36-month return rolling windows. Hence, the analysis period is: January 2002-November 2019.

On the other hand, we obtain quarterly ESG-firm scores of the 4697 stocks from Datastream database. The ESG scoring is the ESG overall-company score obtained by Refinitiv, based on firms' publicly-reported information in the ESG-firm pillars, divided into 10 categories: three environmental (resource use, emissions, and innovation), four social (workforce, human rights, community, and product responsibility), and three governance categories (management, shareholders, and CSR strategy). The ESG score is a weighted average of the underlying 10 category scores, ranging from 0 (lowest) to 1 (highest). ${ }^{3}$ Finally, the monthly OECD-based recession indicator $(0 / 1)$ for the UK is from the Federal Reserve Economic Data ${ }^{4}$ to detect recessions (1) and expansions (0).

\footnotetext{
2 The risk factors are the European factors from French's website: https://mba.tuck. dartmouth.edu/pages/faculty/ken.french/data_library.html.

3 See Refinitiv's webpage for further details: https://www.refinitiv.com/en/sustainablefinance/esg-scores.

${ }^{4}$ https://research.stlouisfed.org/fred2/.
}

\subsection{Variables}

First, we calculate the ESG-fund score, following previous literature (Borgers et al., 2015). We match the quarterly portfolio holdings from Morningstar with the quarterly ESG-firm scores from Datastream. We calculate quarterly ESG-fund scores as the asset-weighted sum of the quarterly ESG-stock scores and the fund weights of all stocks held by each fund:

$$
\text { ESGfund_score }_{i, t}=\sum_{j=1}^{N}\left(\omega_{j, t}^{i} E S G_{j, t}\right)
$$

Where: ESGfund_score $e_{i, t}$ is the ESG score of fund $i$ at quarter $t, \omega_{j, t}^{i}$ is the weight of stock $j$ in fund $i$ at quarter $t, E S G_{j, t}$ is the ESG score of stock $j$ at quarter $t$.

Although portfolio holdings are quarterly, we transform quarterly variables into monthly variables because most of our variables are monthly. Following Brown et al. (2015), we use the data of the previous quarter as monthly proxy (the data of a quarter is applied for the three months included in the next quarter).

Second, we calculate two overlap portfolio measures to analyse portfolio similarities. The first measure shows the quarterly average percentage of common stocks between a conventional (SRI) fund and all SRI (conventional) funds (measure 3). To calculate measure (3), first, we compute measure (2), comparing the quarterly portfolio holdings of conventional (SRI) funds with the portfolio holdings of SRI (conventional) funds by pairs.

Asset_overlap $i j, t=\sum_{n=1}^{N} n_{i, j, t} / N_{i, t}$

Where: Asset_overlap $i j, t$ is the overlap ratio between funds $i$ and $j$ at quarter $t$. When we compare a conventional (SRI) fund with all SRI (conventional) funds, fund $i$ is each conventional (SRI) fund analysed and fund $j$ is all possible SRI (conventional) fund pairs. $\sum_{n=1}^{N} n_{i, j, t}$ is the total number of common stocks between funds $i$ and $j$ at quarter $t$. $N_{i, t}$ is the total number of stocks held by fund $i$ at quarter $t$.

The total overlap ratio of fund $i$ at quarter $t$ is the average of all Asset_overlap $i j, f$ fund pairs of fund $i$ :

Overlap_ratio ${ }_{i, t}=\sum_{m=1}^{M}$ Asset_overlap $_{i j, t} / M_{i, t}$

Where: Overlap_ratio $i, t$ is the portfolio-similarity measure showing the percentage of common stocks of conventional (SRI) fund $i$ at quarter $t$ with all SRI (conventional) portfolios analysed. $M_{i, t}$ is the total possible fund pairs of conventional (SRI) fund $i$ with all SRI (conventional) funds at quarter $t$.

Measure (3) shows portfolio similarities in aggregate terms, focusing on common assets. However, SRI and conventional funds may invest different portfolio weights in common stocks, depending on the ESG-stock score. Measure (5) controls the portfolio similarity considering the asset weight and the ESG-stock score. Nonetheless, first, we calculate measure (4) by fund pairs.

ESGasset_overlap $_{i j, t}=\sum_{n=1}^{N} w_{j, t}^{n} E S G_{n, t} / \sum_{n=1}^{N} w_{i, t}^{n} E S G_{n, t}$

Where: ESGasset_overlap $i j, t$ is the ESG-score overlap ratio between funds $i$ and $j$ at quarter $t$. When we compare a conventional (SRI) fund with all SRI (conventional) funds, fund $i$ is each conventional (SRI) fund analysed and fund $j$ is all possible SRI (conventional) fund pairs with fund $i$ at quarter $t$. $w_{i, t}^{n}$ and $w_{j, t}^{n}$ are the fund weights invested in stock $n$ by funds $i$ and $j$ at quarter $t$, respectively. $E S G_{n, t}$ is the ESG score 
of stock $n$ at quarter $t$, and $N$ is the total stocks held by fund $i$ at quarter $t$.

The total ESG-overlap ratio of fund $i$ at quarter $t$ (measure 5) shows the portfolio similarity considering stocks' weights and ESG scores with regard to their peers.

ESGoverlap_ratio $_{i, t}=\sum_{m=1}^{M}$ ESGasset_overlap $_{i j, t} / M_{i, t}$

Measures (3) and (5) are the dependent variables to study portfolio-similarity drivers. The main independent variables considered as potential drivers are the fund nature (SRI/conventional) and the ESG-fund score. The fund nature is measured with the SRIdummy ${ }_{i t}(1 / 0$ when fund $i$ is/is not a SRI fund). A negative dummy will indicate that SRI funds maintain the expected product differentiation. Conversely, whether conventional funds are improving ESG standards, we expect larger overlap with greater ESG-fund scores.

On the other hand, when we determine the portfolio-similarity impact on ESG-fund scores and performance, measures (3) and (5) are independent variables, and ESG-fund scores and alpha are dependent variables.

The control variables in all models are representative of the main fund characteristics: return, size (TNAs), age, trading activity (turnover-ratio), costs (expense-ratio), and portfolio concentration. The economic phase is also a control variable. Joliet and Titova (2018) find that SRI funds better endure crises; thus, we may expect higher portfolio similarities during crises. The inclusion of some control variables deserves further explanation. The turnover ratio controls for trading because building similar portfolios may imply following others' trading. With regard to the expense ratio, SRI requires additional screening information, increasing expense ratios; however, whether a manager follows others' decisions, information costs may decrease. Additionally, SRI funds may build under-diversified portfolios due to the limited ESG-investment universe (Aslaksen and Synnestwedt 2003; Barnett and Solomon 2006). Whether SRI and conventional funds considering ESG criteria invest in a reduced universe and develop more alike portfolios, they may build more concentrated portfolios. We calculate portfolio concentration with the Herfindahl-Hirschman Index (Hirschman 1964).

$H H I_{i, t}=\sum_{j=1}^{N}\left(\omega_{j, t}^{i}\right)^{2}$

Where: $H_{H} I_{i, t}$ is the Herfindahl-Hirschman Index of fund $i$ at quarter $t$, $\omega_{j, t}^{i}$ is the weight of stock $j$ in fund $i$ at quarter $t$, and $N$ are the total stocks held by fund $i$ at quarter $t$. HHI varies between 0 and 1 .

\subsection{Model specification}

To examine portfolio-similarity drivers and the portfolio-similarity effect on ESG-fund scores and performance, we estimate a set of panel regressions with robust standard errors clustered by fund and time (month) to address heteroskedasticity and correlated error terms. The first estimations include overlap measures (3) and (5) as dependent variables, and the independent and control variables are those described in Section "Variables". Subsequently, we study the influence of portfolio similarities on ESG-fund scores and performance. The independent variables are overlap measures (3) or/and (5) and the aforementioned control variables. All independent variables are lagged to avoid endogeneity issues and capture that portfolio-holding decisions and fund results are commonly based on the most recent information; i.e. the previous period (Anantharaman and Lee 2014).

Our analyses are divided into two parts. First, we analyse all funds (359) to consider the UK domestic-equity universe of pension funds.
However, due to size differences between conventional and SRI samples, we apply the nearest-neighbour matching to select matched conventional funds and avoid biases (Bilbao-Terol et al., 2017; Joliet and Titova 2018). The method matches the control individuals (conventional funds) to the treated group (SRI) with the smallest distance between them on fund characteristics, discarding non-matched control individuals. The propensity score is the similarity measure between funds, estimated with logistic regression on fund characteristics. We use Stata/SE12.0 software to perform the nearest-neighbour matching ${ }^{5}$ and the regressions. ${ }^{6}$ Fig. 1 displays the workflow scheme of the research processes and methods.

\section{Findings and discussion}

\subsection{Summary statistics}

Panel A of Table 1 shows that SRI funds display significantly higher performance, lower size, lower age, higher turnover, lower expenses, higher ESG-fund scores, and lower portfolio similarities (overlap and ESG_overlap ratios). These SRI-fund characteristics are consistent with the SRI-niche tenets. The lower overlaps suggest that SRI funds are not moving away from the ethical purpose and conventional and SRI funds continue building distinct portfolios. Panel B shows that SRI and conventional funds hold controversial stocks (highlighting tobacco), although SRI funds hold lower weights. This conduct may be related to financial outcomes, looking for profits and offsetting ESG limitations. Barnett and Salomon (2006) and Gangi and Varrone (2018) find that SRI funds reduced the ESG standards to achieve similar performance to conventional-fund performance. Nath (2020) points out that the SRI expansion has led to multiple SRI-fund categorization and SRI funds can hold hundreds of holdings with different position on the ESG spectrum. Panel C compares conventional and SRI fund investments considering investee-firms' sectors (according to Morningstar-database sector classification). Both funds develop similar investment patterns. The three main sectors are consumer cyclical, financial services and industrials, while the residual sectors are real estate and utilities. Nevertheless, conventional funds present larger investments in consumer defensive (i.e. foods, beverages or tobacco) and energy (coal and mining) industries, supporting greater controversial-stock investments.

\subsection{ESG-similarity drivers}

Panel A of Table 2 shows that SRI funds present lower portfolio similarities with regard to conventional portfolios (SRI_dummy), holding a lower number of common stocks. Hence, conventional funds consider SRI-fund holdings to a greater extent than SRI funds focus on conventional-fund holdings. This is consistent with the SRI integration into conventional funds. Additionally, funds with larger ESG scores present higher portfolio similarities (significantly positive ESG), given that the limited ESG-asset universe narrows with further ESG standards. Panel B indicate that conventional funds consider weights and ESG-stock scores of SRI funds to a greater extent than SRI funds focus on conventional portfolios (negative SRIdummy). Furthermore, conventional funds with larger similarities on weights and ESG scores present higher ESG scores, lower size, lower turnover, lower expense ratios, and increase similarities during crises. Therefore, conventional funds integrating related ESG strategies to SRI funds develop steadier investment behaviour, consistent with long-term sustainable investments (Joliet and Titova 2018). Furthermore, conventional funds are increasingly interested in

\footnotetext{
5 The nearest-neighbour matching Stata command used is: "psmatch2".

6 The Stata commands of OLS regressions are: "reg" with "robust" and "cluster" options, and "estat vif" to calculate VIFs.
} 


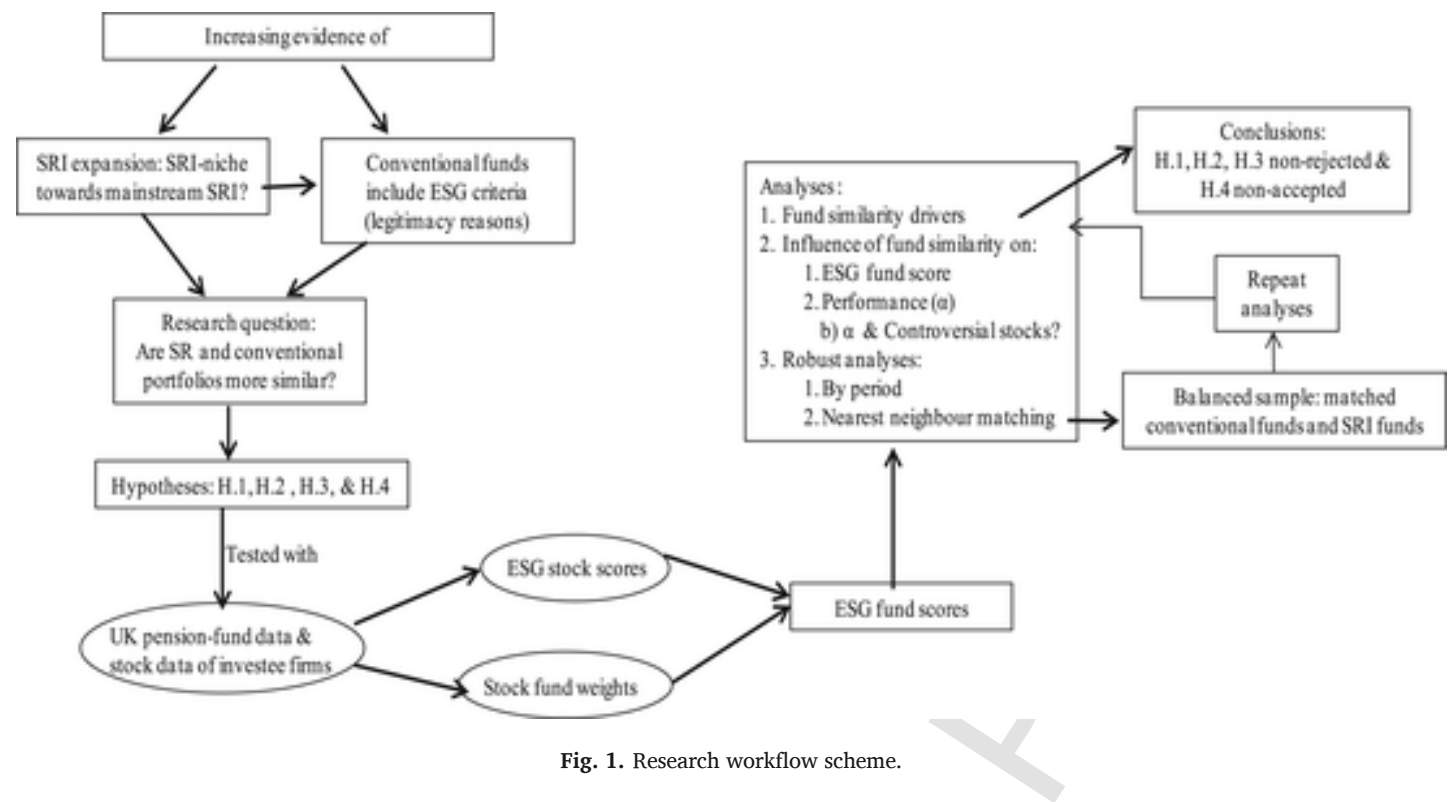

Table 1

Summary statistics. Table 1 is divided into three panels. Panel A shows summary statistics of the monthly variables for all, conventional, and SRI funds. The last column shows the differences between conventional-fund and SRI-fund variables. The significance levels of the differences in means are based on t-tests. *** indicates significance at $1 \%$ level. Panel B shows the portfolio holdings in controversial stocks. Panel C shows the fund investments by investee-stock sector (\%).

Panel A: Fund variables

\begin{tabular}{|c|c|c|c|c|}
\hline & All & Conventional & SRI & Difference \\
\hline Alpha & 0.00133 & 0.0013 & 0.0018 & $-0.0006^{* * *}$ \\
\hline Return & 0.00565 & 0.0057 & 0.0054 & 0.0003 \\
\hline Size & $70.5 * 10^{6}$ & $72.5^{*} 10^{6}$ & $49.4 * 10^{6}$ & $23.1 * 10^{6 * * *}$ \\
\hline Age & 10.54562 & 10.7008 & 9.0822 & $1.6186^{* * *}$ \\
\hline Turnover_ratio & 0.87755 & 0.863 & 1.0087 & $-0.1457^{* * *}$ \\
\hline Expense_ratio & 0.01472 & 0.0148 & 0.0135 & $0.0013^{* * *}$ \\
\hline ESG-fund_score & 0.3714 & 0.3691 & 0.3906 & $-0.0215^{* * *}$ \\
\hline HHI & 0.06277 & 0.0673 & 0.0222 & 0.0451 \\
\hline Overlap_ratio & 0.15025 & 0.1531 & 0.1226 & $0.0305^{* * *}$ \\
\hline ESG-overlap_ratio & 0.74742 & 0.802 & 0.2367 & $0.5653^{* * *}$ \\
\hline \multicolumn{5}{|c|}{ Panel B: Controversial-stock holdings } \\
\hline Tobacco & $2.97 \%$ & $3.14 \%$ & $1.15 \%$ & \\
\hline Gambling & $0.49 \%$ & $0.52 \%$ & $0.17 \%$ & 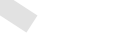 \\
\hline Alcohol & $0.62 \%$ & $0.64 \%$ & $0.46 \%$ & \\
\hline \multicolumn{5}{|c|}{ Panel C: Fund investments: Stock-portfolio holdings by stock sector } \\
\hline Basic Materials & $7.06 \%$ & $7.15 \%$ & $6.09 \%$ & \\
\hline Communication & $5.34 \%$ & $5.18 \%$ & $7.01 \%$ & \\
\hline \multicolumn{5}{|l|}{ Services } \\
\hline Consumer Cyclical & $14.92 \%$ & $14.73 \%$ & $17.02 \%$ & \\
\hline Consumer Defensive & $9.39 \%$ & $9.62 \%$ & $6.91 \%$ & \\
\hline Energy & $10.27 \%$ & $10.58 \%$ & $6.91 \%$ & \\
\hline Financial Services & $17.64 \%$ & $17.33 \%$ & $20.94 \%$ & \\
\hline Healthcare & $7.93 \%$ & $7.99 \%$ & $7.36 \%$ & \\
\hline Industrials & $15.67 \%$ & $15.78 \%$ & $14.49 \%$ & \\
\hline Real Estate & $2.59 \%$ & $2.59 \%$ & $2.56 \%$ & \\
\hline Technology & $5.71 \%$ & $5.68 \%$ & $6.00 \%$ & \\
\hline Utilities & $3.48 \%$ & $3.37 \%$ & $4.70 \%$ & \\
\hline
\end{tabular}

integrating ESG criteria and not only pretending it (consistent with substantive legitimacy-theory strategies, Silva 2021). On the contrary, SRI funds with higher ESG-overlap ratios possess some frequent conventional-fund characteristics, presenting greater age, higher turnover, larger expense ratios, and lower portfolio concentration. Finally, the average variance inflation factors (VIFs) do not show multicollinearity problems (VIFs less than two). ${ }^{7}$

\subsection{The influence of ESG-fund similarities}

We study whether increasing portfolio similarities is a strategy to incorporate the SRI into traditional management, rising (decreasing) the ESG-fund level of conventional (SRI) funds. Table 3 shows that greater overlap ratios (measures 3 and 5) increase ESG-fund scores (columns 2-4). Hence, commonalities between SRI and conventional funds are based on superior ESG stocks, confirming the SRI integration into conventional funds. Furthermore, SRI funds achieve higher ESG-fund scores (significantly positive SRI_dummy), showing that SRI funds maintain superior ethical standards. This evidence is consistent with Hypotheses $1-2$.

Regarding the influence of portfolio-similarities on performance, Table 4 shows that the SRI fund nature does not affect performance (non-significant SRIdummy). The positive influence of the ESG-fund score (column 1) disappears when overlap measures are included. Columns (2) and (4) show that greater common stocks between conventional and SRI funds improve performance (positive Overlap), consistent with the pressure on prices produced by the larger demand of ESG stocks (In et al., 2014). However, the negative ESG coefficient in columns (2) and (4) shows that demanding superior ESG standards constraint investment possibilities (Azoulay and Zeller 2006; Revelli 2017). Whether similarities are based on stock weights and ESG scores, performance is also negatively affected (significantly negative ESG_overlap in columns 3 and 4). These results are in line with the SRI-niche principles; that is, larger ESG-fund standards and higher demand of superior ESG stocks narrow the limited ESG universe, negatively affecting performance (Revelli 2017).

Consistent with Hypothesis 3, column (5) shows that conventional funds with greater ESG-fund scores present lower performance. Additionally, conventional funds with more common stocks with SRI portfolios outperform (positive Overlap). Nevertheless, conventional funds developing similar strategies to SRI funds regarding weights and ESG-scores possess lower performance (ESG_overlap). Although previous

\footnotetext{
7 The VIFs of all models developed in this paper are largely lower than 10, a threshold for multicollinearity detection (Cullinan et al., 2017), showing no multi-collinearity concerns.
} 
Table 2

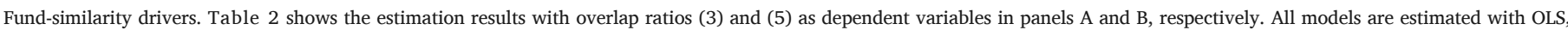
robust standard errors and clustered by fund and month. T-statistics are in parenthesis. *, **, and *** indicate significance at the $10 \%, 5 \%$, and $1 \%$ level, respectively.

\begin{tabular}{|c|c|c|c|c|c|c|}
\hline & \multicolumn{3}{|c|}{ Panel A: Overlap-ratio drivers } & \multicolumn{3}{|c|}{ Panel B: ESG-overlap ratio drivers } \\
\hline & All & Conventional & SRI & All & Conventional & SRI \\
\hline SRI_dummy ${ }_{t}$ & $\begin{array}{l}-0.0059 * * * \\
(-2.62)\end{array}$ & & & $\begin{array}{l}-0.0628^{* * *} \\
(-7.61)\end{array}$ & & \\
\hline $\mathrm{ESG}_{\mathrm{t}-1}$ & $\begin{array}{l}0.3616^{* * *} \\
(42.36)\end{array}$ & $\begin{array}{l}0.3707^{* * *} \\
(42.4)\end{array}$ & $\begin{array}{l}0.1766^{* * *} \\
(8.75)\end{array}$ & $\begin{array}{l}0.7107^{* * *} \\
(18.29)\end{array}$ & $\begin{array}{l}0.7322^{* * * *} \\
(21.14)\end{array}$ & $\begin{array}{l}0.7343^{* * *} \\
(14.89)\end{array}$ \\
\hline Return $_{\mathrm{t}-1}$ & $\begin{array}{l}0.0327 * * \\
(2.35)\end{array}$ & $\begin{array}{l}0.0316^{* *} \\
(2.13)\end{array}$ & $\begin{array}{l}0.0046 \\
(0.21)\end{array}$ & $\begin{array}{l}-0.0603 \\
(-1.17)\end{array}$ & $\begin{array}{l}-0.0537 \\
(-0.97)\end{array}$ & $\begin{array}{l}-0.0576 \\
(-1.09)\end{array}$ \\
\hline Size $_{t-1}$ & $\begin{array}{l}-0.0002^{* * *} \\
(-14.86)\end{array}$ & $\begin{array}{l}-0.0002^{* * *} \\
(-14.46)\end{array}$ & $\begin{array}{l}0.0002 \\
(1.06)\end{array}$ & $\begin{array}{l}-0.0002 \% * * \\
(-4.67)\end{array}$ & $\begin{array}{l}-0.0002^{* * *} \\
(-4.37)\end{array}$ & $\begin{array}{l}-0.0008 \\
(-1.57)\end{array}$ \\
\hline $\mathrm{Age}_{\mathrm{t}-1}$ & $\begin{array}{l}0.0022^{* * *} \\
(8.51)\end{array}$ & $\begin{array}{l}0.0025^{* * *} \\
(9.22)\end{array}$ & $\begin{array}{l}0.0002 \\
(0.36)\end{array}$ & $\begin{array}{l}0.0005 \\
(0.58)\end{array}$ & $\begin{array}{l}-0.0003 \\
(-0.37)\end{array}$ & $\begin{array}{l}-0.0034^{* *} \\
(-2.57)\end{array}$ \\
\hline Turnover $_{\mathrm{t}-1}$ & $\begin{array}{l}-0.001 \\
(-0.91)\end{array}$ & $\begin{array}{l}0.0026^{*} \\
(1.77)\end{array}$ & $\begin{array}{l}-0.0061^{* * *} \\
(-6.16)\end{array}$ & $\begin{array}{l}-0.0093^{* * *} \\
(-3.34)\end{array}$ & $\begin{array}{l}-0.0126^{* * *} \\
(-3.64)\end{array}$ & $\begin{array}{l}0.0057^{* * *} \\
(2.81)\end{array}$ \\
\hline Expense $\mathrm{t}_{\mathrm{t}-1}$ & $\begin{array}{l}0.023^{* * *} \\
(8.34)\end{array}$ & $\begin{array}{l}0.0212^{* * *} \\
(7.54)\end{array}$ & $\begin{array}{l}0.0663^{* * *} \\
(5.82)\end{array}$ & $\begin{array}{l}-0.127^{* k *} \\
(-9.48)\end{array}$ & $\begin{array}{l}-0.14^{* * *} \\
(-10.09)\end{array}$ & $\begin{array}{l}0.1517^{* * * *} \\
(4.17)\end{array}$ \\
\hline $\mathrm{HHI}_{\mathrm{t}-1}$ & $\begin{array}{l}0.3886^{* * *} \\
(2.85)\end{array}$ & $\begin{array}{l}0.3973^{* * *} \\
(2.91)\end{array}$ & $\begin{array}{l}0.5348^{*} \\
(1.82)\end{array}$ & $\begin{array}{l}-0.264 \\
(-0.3)\end{array}$ & $\begin{array}{l}-0.0835 \\
(-0.11)\end{array}$ & $\begin{array}{l}-0.2733^{* * *} \\
(-15)\end{array}$ \\
\hline Crisis $_{\mathrm{t}-1}$ & $\begin{array}{l}-0.0167^{* * *} \\
(-8.59)\end{array}$ & $\begin{array}{l}-0.0187^{* * *} \\
(-9.04)\end{array}$ & $\begin{array}{l}-0.0145^{* * * *} \\
(-5.18)\end{array}$ & $\begin{array}{l}0.0298^{* * *} \\
(4.77)\end{array}$ & $\begin{array}{l}0.032^{* * *} \\
(4.78)\end{array}$ & $\begin{array}{l}0.0339 * * * \\
(4.27)\end{array}$ \\
\hline Constant $_{\mathrm{t}}$ & $\begin{array}{l}0.1258^{* * *} \\
(9.7)\end{array}$ & $\begin{array}{l}0.1112^{* * *} \\
(8.34)\end{array}$ & $\begin{array}{l}0.3847^{* * *} \\
(8.46)\end{array}$ & $\begin{array}{l}-0.4244 * * * \\
(-6.82)\end{array}$ & $\begin{array}{l}-0.4868^{* * *} \\
(-7.76)\end{array}$ & $\begin{array}{l}-0.3765^{* *} \\
(-2.36)\end{array}$ \\
\hline $\mathrm{R}^{2}$ & 0.3894 & 0.6405 & 0.4736 & 0.39 & 0.4109 & 0.6907 \\
\hline VIF & 1.09 & 1.07 & 1.79 & 1.09 & 1.08 & 1.81 \\
\hline
\end{tabular}

Table 3

Similarity-influence on ESG-fund score. Table 3 shows the estimation results for all funds with ESG-fund score (1) as dependent variable. All models are estimated with OLS, robust standard errors and clustered by fund and month. T-statistics are in parenthesis. *, **, and $* * *$ indicate significance at the $10 \%, 5 \%$, and $1 \%$ level, respectively.

\begin{tabular}{|c|c|c|c|c|}
\hline & (1) & (2) & (3) & (4) \\
\hline SRI_dummy $y_{t}$ & $\begin{array}{l}0.0123^{* *} \\
(2.12)\end{array}$ & $\begin{array}{l}0.0154^{* * *} \\
(3.15)\end{array}$ & $\begin{array}{l}0.0346^{* * * *} \\
(5.78)\end{array}$ & $\begin{array}{l}0.0275^{* * *} \\
(5.55)\end{array}$ \\
\hline Overlap_ratio $_{\mathrm{t}-1}$ & & $\begin{array}{l}1.5193^{* * *} \\
(44.68)\end{array}$ & & $\begin{array}{l}1.2679^{* * * *} \\
(36.87)\end{array}$ \\
\hline ESG_overlap $\mathrm{t}-1$ & & & $\begin{array}{l}0.4292^{* * *} \\
(21.57)\end{array}$ & $\begin{array}{l}0.2178^{* * * *} \\
(15.39)\end{array}$ \\
\hline Return $_{\mathrm{t}-1}$ & $\begin{array}{l}-0.039 \\
(-0.75)\end{array}$ & $\begin{array}{l}-0.0552^{*} \\
(-1.79)\end{array}$ & $\begin{array}{l}-0.0109 \\
(-0.26)\end{array}$ & $\begin{array}{l}-0.0366 \\
(-1.31)\end{array}$ \\
\hline Size $_{t-1}$ & $\begin{array}{l}0.0002^{* * *} \\
(5.61)\end{array}$ & $\begin{array}{l}0.0004^{* * *} \\
(11.68)\end{array}$ & $\begin{array}{l}0.0002 * * * \\
(6.01)\end{array}$ & $\begin{array}{l}0.0004 * * * \\
(10.99)\end{array}$ \\
\hline $\operatorname{Age}_{t-1}$ & $\begin{array}{l}0.0011 \\
(1.23)\end{array}$ & $\begin{array}{l}-0.0029 * * * \\
(-5.25)\end{array}$ & $\begin{array}{l}0.0007 \\
(1.03)\end{array}$ & $\begin{array}{l}-0.0023^{* * *} \\
(-5)\end{array}$ \\
\hline Turnover $_{\mathrm{t}-1}$ & $\begin{array}{l}0.0106^{* * *} \\
(5.12)\end{array}$ & $\begin{array}{l}0.0065^{* * *} \\
(3.27)\end{array}$ & $\begin{array}{l}0.0125^{* * *} \\
(6.09)\end{array}$ & $\begin{array}{l}0.0078^{* * * *} \\
(4.14)\end{array}$ \\
\hline Expense_ratio $_{\mathrm{t}-1}$ & $\begin{array}{l}-0.0383^{* * *} \\
(-7.41)\end{array}$ & $\begin{array}{l}-0.0533^{* * *} \\
(-11.9)\end{array}$ & $\begin{array}{l}0.0265^{* * *} \\
(4.01)\end{array}$ & $\begin{array}{l}-0.0188^{* \cdots *} \\
(-4.2)\end{array}$ \\
\hline Crisis $_{\mathrm{t}-1}$ & $\begin{array}{l}-0.0291 * * * \\
(-5.05)\end{array}$ & $\begin{array}{l}0.0119 * * * \\
(2.95)\end{array}$ & $\begin{array}{l}-0.0322^{* * * *} \\
(-6.71)\end{array}$ & $\begin{array}{l}0.0052 \\
(1.4)\end{array}$ \\
\hline Constant $_{t}$ & $\begin{array}{l}0.213^{* * *} \\
(9.01)\end{array}$ & $\begin{array}{l}-0.1106^{* * * *} \\
(-5.24)\end{array}$ & $\begin{array}{l}0.3268^{* * *} \\
(11.66)\end{array}$ & $\begin{array}{l}-0.0052 \\
(-0.26)\end{array}$ \\
\hline $\mathrm{R}^{2}$ & 0.0347 & 0.5817 & 0.3299 & 0.6417 \\
\hline VIF & 1.07 & 1.09 & 1.10 & 1.17 \\
\hline
\end{tabular}

studies find that ESG-integration strategies are less stringent (Revelli 2017), our results show that conventional funds face SRI-integration difficulties. Thus, imitating SRI strategies does not fully incorporate ethics in finance, and conventional funds also need to manage the SRI factor. Column (6) shows that the performance of SRI funds is not affected by the ESG-fund score and the ESG_overlap ratio. However, larger common-stock overlap improves performance. These results are consistent with the lower portfolio imitation of SRI funds.

\subsection{Controversial stocks' influence}

Table 1 shows that conventional and SRI funds hold controversial stocks, although weights are not large. Conventional funds may maintain these stocks to offset the financial penalty of superior ESG standards, as we found in Table 4. However, holding these sensitive stocks by SRI funds may discredit their ethics. Consistent with mainstream-SRI detractors, it seems necessary to question whether the bankable of ethics leads to forget the aim of SRI funds, based on excluding investments deemed unethical (Revelli 2017).

Table 5 shows that larger holdings on tobacco/alcohol firms improve/reduce conventional-funds' performance. In line with Hypothesis 4, these stocks can offset financial penalties due to ESG constraints in conventional funds. Nevertheless, our evidence is limited to support Hypothesis 4. Alternatively, larger tobacco/gambling holdings in SRI funds increase/reduce performance, showing the negative effect of diverting from their ethical purposes. Novethic (2010) indicates that combining ESG-integration and SRI may increase the risk of false advertising, misrepresenting the ESG practices applied. Thus, it is necessary to maintain rigorous structured SRI funds since, in general, we find that SRI funds apply additional ESG screenings.

\subsection{Robustness tests}

\subsubsection{Sub-period analysis}

In this section we study whether results vary due to the mainstream-SRI evolution. Our overlap ratios show two trends, increasing from 2004 to 2012 and decreasing from 2013 to 2019. We separate the sample in these sub-periods and repeat prior analyses. Panels A and B of Table 6 confirm that SRI funds present lower portfolio similarities. Higher ESG scores increase portfolio similarities of conventional and SRI funds in the first sub-period. However, ESG scores do not influence 
Table 4

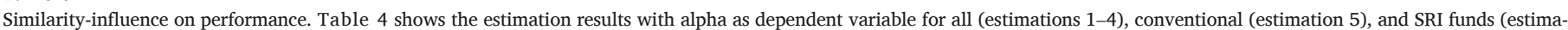

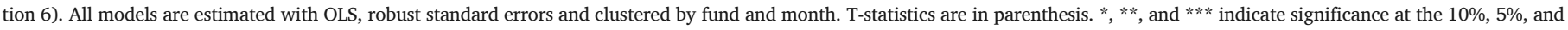
$1 \%$ level, respectively.

\begin{tabular}{|c|c|c|c|c|c|c|}
\hline & (1) & (2) & (3) & (4) & (5)Conventional & (6)SRI \\
\hline SRI_dummy & $\begin{array}{l}0.0001 \\
(0.41)\end{array}$ & $\begin{array}{l}0.0005 \\
(1.54)\end{array}$ & $\begin{array}{l}0.0000 \\
(0.06)\end{array}$ & $\begin{array}{l}0.0003 \\
(0.9)\end{array}$ & & \\
\hline $\mathrm{ESG}_{\mathrm{t}-1}$ & $\begin{array}{l}0.003^{* * *} \\
(3.37)\end{array}$ & $\begin{array}{l}-0.0055^{* * *} \\
(-4.15)\end{array}$ & $\begin{array}{l}0.0072^{* * *} \\
(7.49)\end{array}$ & $\begin{array}{l}-0.0028^{*} \\
(-1.95)\end{array}$ & $\begin{array}{l}-0.0044 * * * \\
(-2.97)\end{array}$ & $\begin{array}{l}-0.0005 \\
(-0.11)\end{array}$ \\
\hline Overlap $\mathrm{t}-1$ & & $\begin{array}{l}0.0264 * * * \\
(9.68)\end{array}$ & & $\begin{array}{l}0.0273^{* * *} \\
(10.07)\end{array}$ & $\begin{array}{l}0.0297^{* * * *} \\
(10.68)\end{array}$ & $\begin{array}{l}0.0484^{* * * *} \\
(4.5)\end{array}$ \\
\hline ESG_overlapt-1 $_{\text {t }}$ & & & $\begin{array}{l}-0.0045^{* * *} \\
(-5.98)\end{array}$ & $\begin{array}{l}-0.0047^{* * * *} \\
(-6.55)\end{array}$ & $\begin{array}{l}-0.0044^{* * *} \\
(-5.62)\end{array}$ & $\begin{array}{l}0.0006 \\
(0.13)\end{array}$ \\
\hline Return $_{\mathrm{t}-1}$ & $\begin{array}{l}-0.002 \\
(-1.04)\end{array}$ & $\begin{array}{l}-0.0026 \\
(-1.38)\end{array}$ & $\begin{array}{l}-0.002 \\
(-1.03)\end{array}$ & $\begin{array}{l}-0.0026 \\
(-1.37)\end{array}$ & $\begin{array}{l}-0.0021 \\
(-1.03)\end{array}$ & $\begin{array}{l}-0.0059 \\
(-1.43)\end{array}$ \\
\hline Size $_{t-1}$ & $\begin{array}{l}0.000 \\
(-1.23)\end{array}$ & $\begin{array}{l}0.0001 * * \\
(2.23)\end{array}$ & $\begin{array}{l}0.0000 \\
(-1.26)\end{array}$ & $\begin{array}{l}0.0001^{* *} \\
(2.07)\end{array}$ & $\begin{array}{l}0.0001^{*} \\
(1.68)\end{array}$ & $\begin{array}{l}0.0001^{* * *} \\
(3.13)\end{array}$ \\
\hline Age $_{t-1}$ & $\begin{array}{l}0.0004^{* * *} \\
(11.75)\end{array}$ & $\begin{array}{l}0.0003^{* * *} \\
(9.34)\end{array}$ & $\begin{array}{l}0.0004^{* * *} \\
(11.76)\end{array}$ & $\begin{array}{l}0.0003^{* * *} \\
(9.34)\end{array}$ & $\begin{array}{l}0.0003^{* * *} \\
(7.74)\end{array}$ & $\begin{array}{l}0.0008^{* * * *} \\
(9.39)\end{array}$ \\
\hline Turnover $_{\mathrm{t}-1}$ & $\begin{array}{l}-0.0006^{* * *} \\
(-5.98)\end{array}$ & $\begin{array}{l}-0.0006^{* * *} \\
(-5.75)\end{array}$ & $\begin{array}{l}-0.0007^{* * *} \\
(-6.43)\end{array}$ & $\begin{array}{l}-0.0006^{* * * *} \\
(-5.79)\end{array}$ & $\begin{array}{l}-0.001^{* * *} \\
(-7.52)\end{array}$ & $\begin{array}{l}0.0001 \\
(0.62)\end{array}$ \\
\hline Expense_ratio $_{t-1}$ & $\begin{array}{l}-0.0869 * * \\
(-2.26)\end{array}$ & $\begin{array}{l}-0.1995 * * * \\
(-4.84)\end{array}$ & $\begin{array}{l}-0.1626^{* * *} \\
(-3.71)\end{array}$ & $\begin{array}{l}-0.2815^{* * *} \\
(-6.53)\end{array}$ & $\begin{array}{l}-0.2501 * * * \\
(-5.28)\end{array}$ & $\begin{array}{l}-0.7826^{* * * *} \\
(-6.4)\end{array}$ \\
\hline Crisis $_{\mathrm{t}-1}$ & $\begin{array}{l}-0.0051^{* * *} \\
(-21.08)\end{array}$ & $\begin{array}{l}-0.0046^{* * *} \\
(-18.75)\end{array}$ & $\begin{array}{l}-0.0049^{* * *} \\
(-19.65)\end{array}$ & $\begin{array}{l}-0.0044^{* * * *} \\
(-17.99)\end{array}$ & $\begin{array}{l}-0.0044^{* * *} \\
(-16.88)\end{array}$ & $\begin{array}{l}-0.0027 * * * \\
(-4.6)\end{array}$ \\
\hline Constant $_{\mathrm{t}}$ & $\begin{array}{l}0.0008 \\
(1.02)\end{array}$ & $\begin{array}{l}0.0012 \\
(1.51)\end{array}$ & $\begin{array}{l}0.0019 * * \\
(2.11)\end{array}$ & $\begin{array}{l}0.003^{* * *} \\
(3.54)\end{array}$ & $\begin{array}{l}0.003^{* * *} \\
(3.25)\end{array}$ & $\begin{array}{l}0.0002 \\
(0.09)\end{array}$ \\
\hline $\mathrm{R}^{2}$ & 0.2926 & 0.3328 & 0.3106 & 0.3462 & 0.3481 & 0.6132 \\
\hline VIF & 1.08 & 1.47 & 1.20 & 1.53 & 1.60 & 1.89 \\
\hline
\end{tabular}

Table 5

Controversial-sector stocks' influence on performance. Table 5 shows the results including controversial-sector holdings as independent variables to analyse their influence on alpha for all, conventional, and SRI funds. All models are estimated with OLS, robust standard errors and clustered by fund and month. Control-variable results are not displayed and available upon request. T-statistics are in parenthesis. *, **, and *** indicate significance at the $10 \%, 5 \%$, and $1 \%$ level, respectively.

\begin{tabular}{llll} 
& All & Conventional & SRI \\
\hline SRI_dummyt & 0.0004 & & \\
& $(1.37)$ & & \\
ESG $_{\mathrm{t}-1}$ & $0.0023^{* * *}$ & $0.002^{* *}$ & $0.0087^{* *}$ \\
& $(2.28)$ & $(1.97)$ & $(2.25)$ \\
Tobacco $_{\mathrm{t}-1}$ & $0.0105^{* * *}$ & $0.0088^{* * *}$ & $0.0225^{* *}$ \\
& $(3.36)$ & $(2.72)$ & $(2.05)$ \\
Gambling $_{\mathrm{t}-1}$ & 0.0215 & 0.0207 & $-0.1722^{* *}$ \\
& $(1.3)$ & $(1.24)$ & $(-2.31)$ \\
Alcohol $_{\mathrm{t}-1}$ & $-0.0287^{* * *}$ & $-0.0318^{* * *}$ & -0.0077 \\
& $(-3.8)$ & $(-3.8)$ & $(-0.46)$ \\
Constant $_{\mathrm{t}}$ & 0.0014 & 0.0011 & 0.0025 \\
\multirow{2}{*}{$\mathrm{R}^{2}$} & $(1.55)$ & $(1.17)$ & $(1.02)$ \\
VIF & 0.2847 & 0.2827 & 0.5912 \\
\hline
\end{tabular}

(negatively influence) conventional (SRI) funds in the second period, indicating that funds are modifying their conducts. Conventional funds initially integrated ESG practices by benchmarking SRI funds (positive ESG-coefficient in the first period). However, conventional funds with larger ESG scores reduce the SRI-portfolio imitation in the second period, probably because the previous experience allows them to develop their own ESG management. On the contrary, conventional funds with poorer ESG scores consider SRI portfolios to learn about ESG assets. SRI funds with superior ESG standards also move away from conventional portfolios in the second period, developing distinct strategies.
Panel C shows that SRI funds present larger ESG scores in the first period. A higher Overlap_ratio increases ESG scores of conventional and SRI funds in both periods. However, greater ESG_overlap positively/negatively influence ESG scores in the first/second period. This supports a change in the ESG-investment trend during the second period; i.e., conventional and SRI funds applying superior ESG strategies are evolving in the ESG-integration and SRI-preservation, respectively, developing consistent strategies with their nature.

Panel A of Table 7 shows that the SRI-fund nature does not significantly influence performance, consistent with Table 4. Panel B shows that conventional funds with higher ESG scores achieve lower performance in both periods, indicating that conventional funds with superior ESG integration approximate to the SRI-niche principles (especially since 2013), based on the selection of ESG assets causing management constraints (Azoulay and Zeller 2006; Revelli 2017). Regarding overlap measures, in the first period, conventional funds with more common stocks improve performance, but increasing ESG_overlap similarities decreases performance. Panel C does not display significant ESG-score influence on SRI-fund performance, and a greater Overlap_ratio improves/deteriorates performance in the first/second period. This suggests that SRI funds return to SRI-niche principles in the second period, preserving their ethical purposes, although the mainstream-SRI has filled the conventional management through ESG-integration.

\subsubsection{Nearest-neighbour matching}

We apply the nearest-neighbour matching process to provide a more balance conventional-fund sample. The process provides 28 matched conventional funds (the SRI sample is formed of 28 funds). Fig. 2 shows the better balance of the matched variables with regard to unmatched variables. We repeat previous analyses to determine the robustness of the results. The results of Table A.1 in the Appendix show that our main conclusions hold. Table 8 compares previous and current results and displays three significant differences. Panels A.1 and B.1 show that the SRI dummy turns from significantly negative to non- 
Table 6

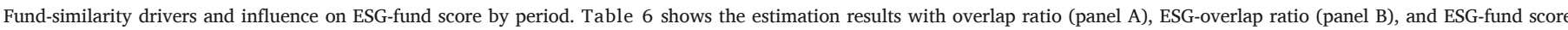

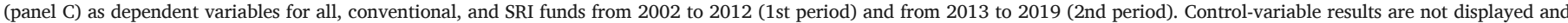
available upon request. T-statistics are in parenthesis. *, **, and *** indicate significance at the $10 \%, 5 \%$, and $1 \%$ level, respectively.

\begin{tabular}{|c|c|c|c|c|c|c|}
\hline \multicolumn{7}{|c|}{ Panel A: Overlap ratio } \\
\hline & \multicolumn{2}{|l|}{ All } & \multicolumn{2}{|c|}{ Conventional } & \multicolumn{2}{|l|}{ SRI } \\
\hline & $1^{\text {st }}$ period & $2^{\text {nd }}$ period & $1^{\text {st }}$ period & $2^{\text {nd }}$ period & $1^{\text {st }}$ period & $2^{\text {nd }}$ period \\
\hline SRI_dummy ${ }_{t}$ & $\begin{array}{l}-0.0057^{* *} \\
(-2.53)\end{array}$ & $\begin{array}{l}-0.0381 * * \\
(-2.13)\end{array}$ & & & & \\
\hline $\mathrm{ESG}_{\mathrm{t}-1}$ & $\begin{array}{l}0.362^{* * *} \\
(43.41)\end{array}$ & $\begin{array}{l}-0.1162 \\
(-0.8)\end{array}$ & $\begin{array}{l}0.3714^{* * *} \\
(43.49)\end{array}$ & $\begin{array}{l}0.032 \\
(0.16)\end{array}$ & $\begin{array}{l}0.1774^{* * * *} \\
(8.79)\end{array}$ & $\begin{array}{l}-0.092^{* *} \\
(-2.41)\end{array}$ \\
\hline Control_variables & Yes & Yes & Yes & Yes & Yes & Yes \\
\hline $\mathrm{R}^{2}$ & 0.6173 & 0.971 & 0.6363 & 0.9718 & 0.4758 & 0.8936 \\
\hline VIF & 1.08 & 2.01 & 1.07 & 1.57 & 1.79 & 1.70 \\
\hline \multicolumn{7}{|c|}{ Panel B: ESG-overlap ratio } \\
\hline SRI_dummy $_{t}$ & $\begin{array}{l}-0.0607^{* * *} \\
(-7.46)\end{array}$ & $\begin{array}{l}-0.2198 * * * \\
(-2.69)\end{array}$ & & & & \\
\hline $\mathrm{ESG}_{\mathrm{t}-1}$ & $\begin{array}{l}0.711^{* * *} \\
(18.98)\end{array}$ & $\begin{array}{l}-0.5468 \\
(-1.42)\end{array}$ & $\begin{array}{l}0.7325^{* * *} \\
(21.92)\end{array}$ & $\begin{array}{l}-0.9885^{*} \\
(-1.78)\end{array}$ & $\begin{array}{l}0.6899 * * * \\
(14.36)\end{array}$ & $\begin{array}{l}-0.3704^{* * * *} \\
(-5.14)\end{array}$ \\
\hline Control_variables & Yes & Yes & Yes & Yes & Yes & Yes \\
\hline $\mathrm{R}^{2}$ & 0.3872 & 0.9615 & 0.4093 & 0.9631 & 0.6908 & 0.9051 \\
\hline VIF & 1.08 & 2.00 & 1.07 & 1.57 & 1.79 & 1.66 \\
\hline \multicolumn{7}{|c|}{ Panel C: ESG-fund score } \\
\hline SRI_dummy $_{t}$ & $\begin{array}{l}0.0271^{* * *} \\
(5.42)\end{array}$ & $\begin{array}{l}-0.0332 \\
(-1.2)\end{array}$ & & & & \\
\hline Overlap_ratio $_{\mathrm{t}-1}$ & $\begin{array}{l}1.2667^{* * *} \\
(36.33)\end{array}$ & $\begin{array}{l}0.6964 \\
(1.66)\end{array}$ & $\begin{array}{l}1.2609^{* * *} \\
(34.74)\end{array}$ & $\begin{array}{l}1.1862^{* * *} \\
(2.96)\end{array}$ & $\begin{array}{l}1.5187^{* * *} \\
(12.31)\end{array}$ & $\begin{array}{l}1.3384^{* * * *} \\
(4.2)\end{array}$ \\
\hline ESG_overlapt-1 $_{\text {- }}$ & $\begin{array}{l}0.2264^{* * *} \\
(15.5)\end{array}$ & $\begin{array}{l}-0.2642^{* * *} \\
(-3.04)\end{array}$ & $\begin{array}{l}0.2343^{* * *} \\
(15.27)\end{array}$ & $\begin{array}{l}-0.3995^{* * *} \\
(-4.61)\end{array}$ & $\begin{array}{l}0.1788^{* * *} \\
(3.25)\end{array}$ & $\begin{array}{l}-1.3537^{* * *} \\
(-7.21)\end{array}$ \\
\hline Control_variables & Yes & Yes & Yes & Yes & Yes & Yes \\
\hline $\mathrm{R}^{2}$ & 0.6462 & 0.8645 & 0.6629 & 0.884 & 0.5818 & 0.6342 \\
\hline VIF & 1.16 & 2.12 & 1.17 & 1.77 & 1.56 & 1.64 \\
\hline
\end{tabular}

Table 7

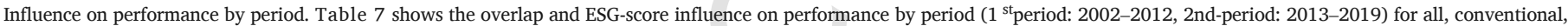

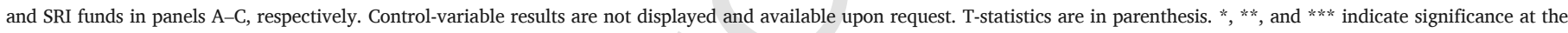
$10 \%, 5 \%$, and $1 \%$ level, respectively.

\begin{tabular}{|c|c|c|c|c|c|c|}
\hline \multirow[t]{2}{*}{ Panel A: All } & \multicolumn{4}{|c|}{ Panel B: Conventional } & \multicolumn{2}{|c|}{ Panel C: SRI } \\
\hline & $1^{\text {st }}$ period & $2^{\text {nd }}$ period & $1^{\text {st }}$ period & $2^{\text {nd }}$ period & $1^{\text {st }}$ period & $2^{\text {nd }}$ period \\
\hline SRI_dummy ${ }_{t}$ & $\begin{array}{l}0.0002 \\
(0.74)\end{array}$ & $\begin{array}{l}0.0039 \\
(1.48)\end{array}$ & & & & \\
\hline $\mathrm{ESG}_{\mathrm{t}-1}$ & $\begin{array}{l}-0.0016 \\
(-1.08)\end{array}$ & $\begin{array}{l}-0.0309^{* *} \\
(-3.33)\end{array}$ & $\begin{array}{l}-0.003^{* *} \\
(-2.04)\end{array}$ & $\begin{array}{l}-0.0464^{* * * *} \\
(-3.62)\end{array}$ & $\begin{array}{l}-0.0007 \\
(-0.15)\end{array}$ & $\begin{array}{l}0.0002 \\
(0.08)\end{array}$ \\
\hline Overlap ${ }^{\mathrm{t}-1}$ & $\begin{array}{l}0.0253^{* * *} \\
(9.32)\end{array}$ & $\begin{array}{l}0.0012 \\
(0.06)\end{array}$ & $\begin{array}{l}0.0276^{* * * k} \\
(9.91)\end{array}$ & $\begin{array}{l}0.0366 \\
(1.29)\end{array}$ & $\begin{array}{l}0.0502^{* * *} \\
(4.61)\end{array}$ & $\begin{array}{l}-0.0176^{* *} \\
(-1.99)\end{array}$ \\
\hline ESG_overlap $_{\mathrm{t}-1}$ & $\begin{array}{l}-0.005^{* * *} \\
(-6.72)\end{array}$ & $\begin{array}{l}0.0128^{* * *} \\
(2.78)\end{array}$ & $\begin{array}{l}-0.0047 * * * \\
(-5.9)\end{array}$ & $\begin{array}{l}0.0019 \\
(0.29)\end{array}$ & $\begin{array}{l}0.0008 \\
(0.17)\end{array}$ & $\begin{array}{l}-0.0083 \\
(-1.66)\end{array}$ \\
\hline Control_variables & Yes & Yes & Yes & Yes & Yes & Yes \\
\hline $\mathrm{R}^{2}$ & 0.354 & 0.9515 & 0.3559 & 0.9547 & 0.6189 & 0.4409 \\
\hline VIF & 1.51 & 2.09 & 1.59 & 1.97 & 1.89 & 1.85 \\
\hline
\end{tabular}

significant (the SRI-fund nature does not influence common-stock overlapping). However, this dummy remains significantly negative in panels A.2-B.2, reinforcing our prior arguments about the larger imitation of conventional funds in selecting stocks with greater ESG standards. Second, the influence of the SRI-nature on ESG-fund scores turns from positive to non-significant (panels A.3-B.3). These differences indicate that matched conventional funds are more alike SRI funds and the latter do not necessarily achieve larger ESG-fund scores; hence, matched-conventional funds are able to develop portfolios with similar ESG standards to SRI-fund portfolios. Panel B.3 also shows that the SRI-nature negatively influences performance. Again, comparing more alike conventional and SRI funds, SRI funds achieve lower performance, consistent with the larger constraints of the SRI. Despite these differences, we find support for our previous results, concluding that conventional funds are immersed in the ESG-inclusion to attend the evolving values and concerns of stakeholders. Conversely, SRI funds follow applying SRI tenets. 


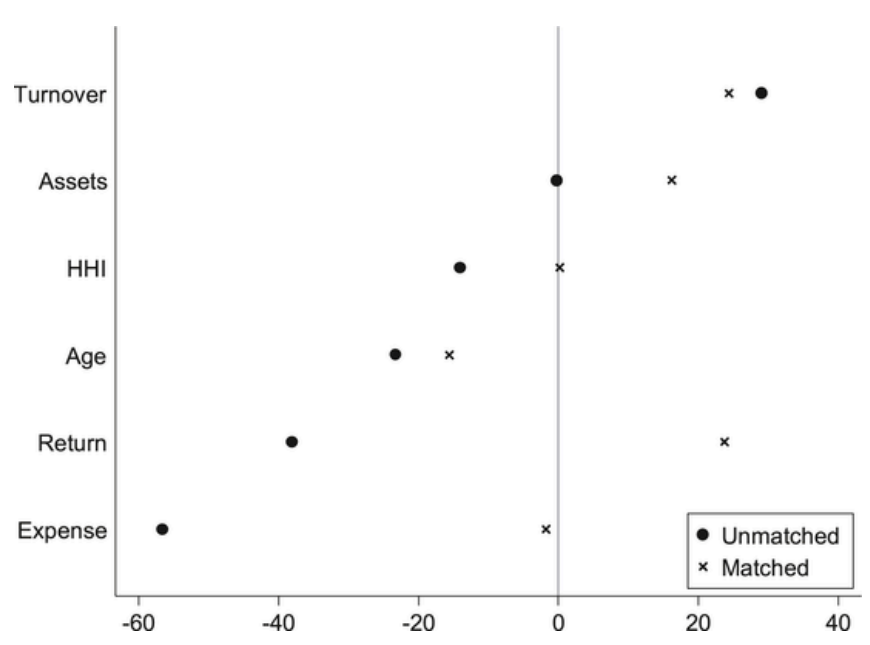

Fig. 2. Unmatched versus matched samples. Fig. 2 compares the conventional-fund variables before (unmatched) and after (matched) applying the nearest-neighbour matching with the standardised bias across covariates (in percentage).

Table 8

Result comparison with unmatched and matched samples.

Table 8 compares the main results with all (panel A) and matched conventional and SRI funds (panel B), indicating if the coefficients are significantly-positive $(+)$, significantly-negative(-) or non-significant (Non-sig). Differences are grey-shading (panel B). Panels A.1-B.1 show the results with overlap ratio (3) as dependent variable. Panels A.2-B.2 show the results with ESG-overlap ratio (5) as dependent variable. Panels A.3-B.3 show the results with ESG-fund score (1) and alpha as dependent variables.

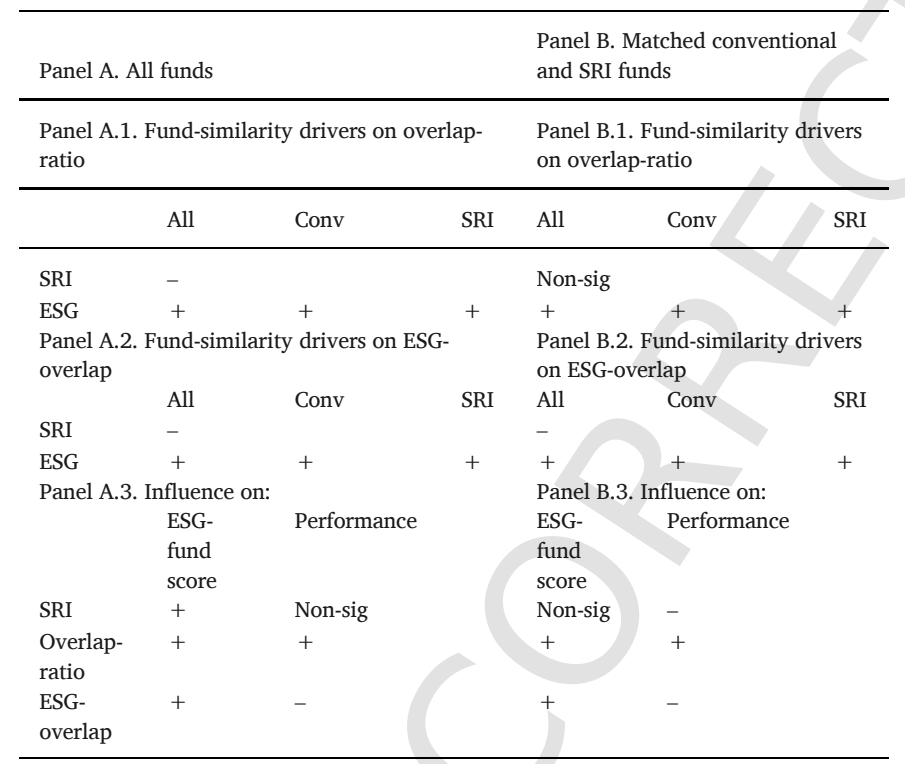

\section{Conclusions}

This study analyses the mainstream-SRI phenomenon in conventional pension funds, which are increasingly integrating ESG-investment criteria, as part of a legitimacy process. While SRI funds are specialised on ESG assets, conventional funds are recent actors in the SRI. We then examine whether conventional funds consider the firms in which SRI funds invest to integrate ESG factors. We analyse similarities between conventional and SRI funds, considering common stocks, portfolio weights, and ESG-stock scores. The mainstream SRI also raises the need to evaluate whether the mainstream SRI is diverting SRI funds from ethical purposes.
Our results show that conventional funds present large similarities to SRI funds on larger ESG-scored investee firms, suggesting that conventional funds consider the SRI-fund holdings to integrate ESG criteria. Consistent with Hoepner and Schopohl (2020) and legitimacy theory, our evidence shows that pension funds may be adopting a more holistic interpretation of beneficiaries' interests, including financial and non-financial concerns. Additionally, the commonalities between SRI and conventional funds on superior ESG stocks support the SRI integration among conventional funds. In line with legitimacy theory, our results indicate that conventional funds may be following ESG strategies as mechanism to reach appropriate investments for their relevant publics. However, SRI funds continue applying larger ESG standards, that is, it seems that SRI funds desire to maintain their legitimacy and ethical purposes. The mainstream SRI does not appear to be turning SRI as packaged, co-existing a large variety of SRI and conventional funds. Our findings also suggest that the incipient inclusion of ESG criteria by conventional funds was based on benchmarking SRI portfolios, but pioneer conventional funds considering ESG criteria have evolved in the ESG-integration.

Although our study presents some interesting results, some limitations should be highlighted. The UK possesses the second most important worldwide pension-fund industry; however, the analysis is restricted to UK domestic equity pension funds, and some results may not be generalised to other markets. Furthermore, the SRI-fund sample is reduced due to data limitations (the SRI pension-fund niche is still expanding). It would also be interesting to study other asset classes and markets. This research will also allow solidifying the sustainability of financial markets.

\section{Declaration of competing interest}

The authors declare that they have no known competing financial interests or personal relationships that could have appeared to influence the work reported in this paper.

\section{Acknowledgments}

This word was supported by Ibercaja and University of Zaragoza [JIUZ-2020-SOC-02], Spanish Ministry of Science and Innovation and ERDF [RTI2018-093483-B-I00] and Government of Aragon [S38_17R].

\section{Appendix.}

Table A.1

Results with nearest-neighbour matching. Panels A-B show the results with overlap (3) and ESG-overlap (5) ratios as dependent variables. Panel C shows the results with ESG-fund score (1) as dependent variable for matched conventional and SRI funds. Panel D shows the results with alpha as dependent variable for matched conventional and SRI funds (estimations 1-4), matched conventional (5), and SRI funds (estimation 6). Panel E shows the results including controversial-sector holdings to analyse their influence on the performance of matched conventional and SRI funds, matched conventional, and SRI funds. All models are estimated with OLS, robust standard errors, and clustered by fund and month. Control-variable results are not displayed and available upon request. T-statistics are in parenthesis. *, **, and *** indicate significance at the $10 \%, 5 \%$, and $1 \%$ level, respectively.

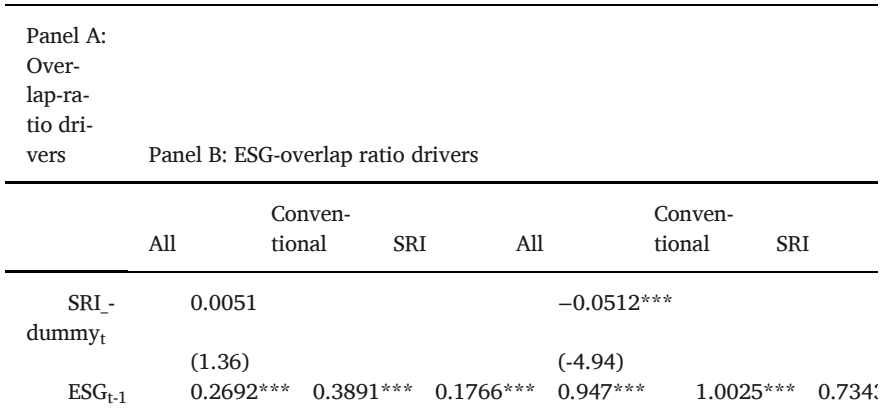




\begin{tabular}{llllll}
\hline & $(12.94)$ & $(14.36)$ & $(8.75)$ & $(26.04)$ & $(25.46)$ \\
$\mathrm{R}^{2}$ & 0.4201 & 0.612 & 0.4736 & 0.5787 & 0.665 \\
$\mathrm{VIF}$ & 1.46 & 1.73 & 1.79 & 1.46 & 1.73 \\
\hline
\end{tabular}

Panel C: Similarity influence on ESG-fund score

\begin{tabular}{|c|c|c|c|c|}
\hline & (1) & (2) & (3) & (4) \\
\hline SRI_dummyt & $\begin{array}{l}0.0046 \\
(0.44)\end{array}$ & $\begin{array}{l}-0.0064 \\
(-0.67)\end{array}$ & $\begin{array}{l}0.0176^{* * *} \\
(2.02)\end{array}$ & $\begin{array}{l}0.0085 \\
(0.96)\end{array}$ \\
\hline Overlap_ratio $\mathrm{t}_{-1}$ & $1.1702^{* * *}$ & (12.93) & $0.565^{* * *}$ & \\
\hline ESG_overlap t-1 & & $0.6301 * * *$ & $\begin{array}{l}0.5133^{* * * * k} \\
(15.45)\end{array}$ & (10.42) \\
\hline Constant $_{t}$ & $\begin{array}{l}0.3354^{* * * *} \\
(2.75)\end{array}$ & $\begin{array}{l}-0.3381^{* * * *} \\
(-4.51)\end{array}$ & $\begin{array}{l}-0.3422^{* * *} \\
(-3)\end{array}$ & $\begin{array}{l}-0.5258^{* * * *} \\
(-5.54)\end{array}$ \\
\hline $\mathrm{R}^{2}$ & 0.101 & 0.333 & 0.4767 & 0.5155 \\
\hline VIF & 1.24 & 1.28 & 1.24 & 1.35 \\
\hline
\end{tabular}

Panel D: Similarity influence on performance

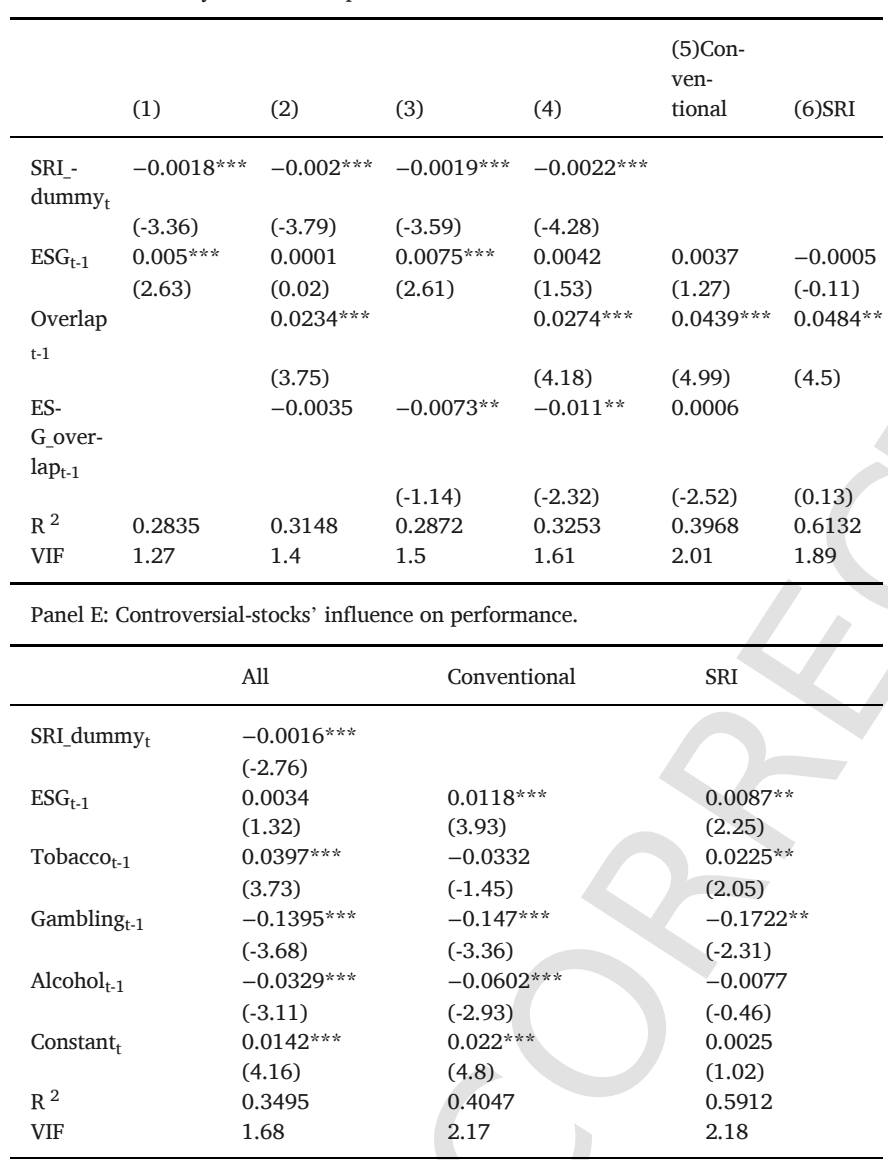

\section{References}

[Anantharaman and Lee, 2014] D. Anantharaman, Y.G. Lee, Managerial risk taking incentives and corporate pension policy, J. Financ. Econ. 111 (2) (2014) 328-351.

[Ashforth and Gibbs, 1990] B.E. Ashforth, B.W. Gibbs, The double-edge of organizational legitimation, Organ. Sci. 1 (1990) 177-194.

[Aslaksen and Synnestwedt, 2003] I. Aslaksen, T. Synnestwedt, Ethical investment and the incentives for corporate environmental Protection and social responsibility, Corp. Soc. Responsib. Environ. Manag. 10 (4) (2003) 212-223.

[Azoulay and Zeller, 2006] O. Azoulay, V. Zeller, ISR: strategie de "niche" ou "mainstream"?, Rev. Econ. Financ. 85 (2006) 273-284.

[Barnett and Salomon, 2006] M.L. Barnett, R.M. Salomon, Beyond dichotomy: the curvilinear relationship between social responsibility and financial performance, Strat. Manag. J. 27 (2006) 1101-1122.
[Bilbao-Terol et al., 2017] A. Bilbao-Terol, S. Álvarez-Otero, C. Bilbao-Terol, V. Cañal-Fernández, Hedonic evaluation of the SRI label of mutual funds using matching methodology, Int. Rev. Financ. Anal. 52 (2017) 213-227.

[Borgers et al., 2015] A. Borgers, J. Derwall, K. Koedijk, J. ter Horst, Do social factors influence investment behavior and performance? Evidence from mutual fund holdings, J. Bank. Finance 60 (2015) 112-126.

[Brown et al., 2015] K.C. Brown, W.V. Harlow, H. Zhang, Investment Style Volatility and Mutual Fund Performance, University of Texas, 2015 Working paper.

[Carhart, 1997] M. Carhart, On persistence in mutual fund performance, J. Finance 52 (1) (1997) 57-82.

[Cullinan et al., 2017] C. Cullinan, L. Mahoney, P. Roush, Are CSR activities associated with shareholder voting in director elections and say-on-pay votes?, J. Contemp. Account. Econ. 13 (2017) 225-243.

[Deegan, 2002] C. Deegan, The legitimising effect of social and environmental disclosures - a theoretical foundation. Accounting, Auditing \& Accountability Journal 15 (3) (2002) 282-311.

[Deegan, 2019] C. Deegan, Legitimacy theory. Accounting, Auditing \& Accountability Journal 32 (2019) 2307-2329.

[Gangi and Varrone, 2018] F. Gangi, N. Varrone, Screening activities by socially responsible funds: a matter of agency?, J. Clean. Prod. 197 (2018) 842-855.

[Hellsten and Mallin, 2006] S. Hellsten, C. Mallin, Are "ethical" or "socially responsible" investments socially responsible?, J. Bus. Ethics 66 (2006) 393-406.

[Hirschman, 1964] A.O. Hirschman, The paternity of an index, Am. Econ. Rev. 54 (1964) 761.

[Hoepner and Schopohl, 2020] A.G.F. Hoepner, L. Schopohl, State pension funds and corporate social responsibility: do beneficiaries' political values influence funds' investment decisions?, J. Bus. Ethics 165 (2020) 489-516.

[Hong and Kacperczyk, 2009] H. Hong, M. Kacperczyk, The price of sin: the effects of social norms on markets, J. Financ. Econ. 93 (2009) 15-36.

[In et al., 2014] F. In, M. Kim, R. Park, S. Kim, T. Kim, Competition of socially responsible and conventional mutual funds and its impact on fund performance, J. Bank. Finance 44 (2014) 160-176.

[Jin and Han, 2018] J. Jin, L. Han, Assessment of Chinese green funds: performance and industry allocation, J. Clean. Prod. 171 (2018) 1084-1093.

[Joliet and Titova, 2018] R. Joliet, Y. Titova, Equity SRI funds vacillate between ethics and money: an analysis of the funds' stock holding decisions, J. Bank. Finance 97 (2018) 70-86.

[Lindblom, 1994] C.K. Lindblom, The implications of organizational legitimacy for corporate social performance and disclosure, Paper Presented at the Critical Perspective on Accounting Conference, 1994 New York.

[Markowitz, 1952] H. Markowitz, Portfolio selection, J. Finance 7 (1) (1952) 77-91.

[Martí-Ballester, 2015] C.P. Martí-Ballester, Can socially responsible investment for cleaner production improve the financial performance of Spanish pension plans?, J. Clean. Prod. 106 (2015) 466-477.

[Matallín-Sáez et al., 2019] J.C. Matallín-Sáez, A. Soler-Domínguez, E. Tortosa-Ausina, D.V. de Mingo-López, Ethical strategy focus and mutual fund management: performance and persistence, J. Clean. Prod. 213 (2019) 618-633.

[McLachlan and Gardner, 2004] J. McLachlan, J. Gardner, A comparison of socially responsible and conventional investors, J. Bus. Ethics 52 (1) (2004) 11-25.

[Nath, 2020] S. Nath, The business of virtue: evidence from socially responsible investing in financial markets, J. Bus. Ethics (2020) forthcoming.

[Novethic, 2010] Novethic, Achieving Investment Objectives through ESG Integration, 2010.

[OECD, 2020] OECD, Pension Markets in Focus 2020, OECD, 2020

[Perez, 2016] D. Perez, Sin stock returns and investor sentiment, Q. Rev. Econ. Finance 59 (2016) 63-70.

[Revelli, 2017] C. Revelli, Socially responsible investing (SRI): from mainstream to margin?, Res. Int. Bus. Finance 39 (2017) 711-717.

[Sandberg, 2013] J. Sandberg, (Re-)Interpreting fiduciary duty to justify socially responsible investment for pension funds?, Corp. Govern. Int. Rev. 21 (5) (2013) 436-446.

[Schiopoiu and Popa, 2013] A. Schiopoiu, I. Popa, Legitimacy theory, in: S. Idowu, N. Capladi, L. Zu, A.D. Gupta (Eds.), Encyclopedia of Corporate Social Responsibility, Springer-Verlag, Berlin, 2013, pp. 1579-1584.

[Sethi, 2005] S.P. Sethi, Investing in socially responsible companies is a must for public pension funds: because there is no better alternative, J. Bus. Ethics 56 (2) (2005) 99-129.

[Sievänen, 2014] R. Sievänen, Practicalities bottleneck to pension fund responsible investment?, Bus. Ethics Eur. Rev. 23 (3) (2014) 309-326.

[Sievänen et al., 2017] R. Sievänen, R. Hannu, B. Scholtens, European pension funds and sustainable development: trade-offs between finance and responsibility, Bus. Strat. Environ. 26 (2017) 912-926.

[Silva and Cortez, 2016] F. Silva, M. Cortez, The performance of US and European green funds in different market conditions, J. Clean. Prod. 135 (2016) $558-566$.

[Silva, 2021] S. Silva, Corporate contributions to the Sustainable Development Goals: an empirical analysis informed by legitimacy theory, J. Clean. Prod. 292 (2021) 125962.

[Suchman, 1995] M. Suchman, Managing legitimacy: strategic and institutional approaches, Acad. Manag. Rev. 20 (3) (1995) 571-610.

[UNEP FI, 2009] UNEP FI, Fiduciary Responsibility: Legal and Practical Aspects of Integrating Environmental, Social and Governance Issues into Institutional Investment, UNEP FI, Geneva, 2009. 
[UKSIF, 2018] UKSIF, New Government Regulation Makes Clear Existing Pension Scheme Duty to Consider ESG Factors, UKSIF, 2018. 